\title{
Maurizio Migliori (ed.) (2020). Il pensiero multifocale, Humanitas, 75(1-2)
}

\section{RICCARDO DI STEFANO}

Università degli Studi di Macerata

This issue of the Journal Humanitas almost entirely focuses on the presentation of the so-called multifocal approach, which has been proposed in the last few years by a group of scholars working in ancient philosophy at the University of Macerata, Italy. A selection of twenty-one papers presented at an international conference in Macerata in 2018, this volume ranges over different subjects from history of philosophy to sociology, from art history to social psychology and economic analyses, although some disciplines are more well represented than others. Together, the contributions aim to offer an interdisciplinary insight into "the complexity of reality" (p. 4), an assumption which is at the core of the multifocal approach.

The work is divided into three main sections: the first, which is also the most extended, deals with topics from history of philosophy and ancient Greek literature ("Il pensiero multifocale nei testi antichi e moderni"); the second focuses on the sociological and cultural aspect of this approach ("Il pensiero multifocale nella dimensione sociologico-culturale"); in the third part, finally, the authors turn to the scientific and economic side ("Il pensiero multifocale nella dimensione scientifico-produttiva"). An Introduction and an Afterword by Maurizio MIGLIORI, placed outside the sections mentioned above, complete this volume.

Before turning to some representative contributions from each of the three sections, let me briefly summarize the Introduction, which contains the guiding principles underlying the multifocal approach. In the opening lines, MIGLIORI clarifies that this approach stems from the study of ancient philosophers, most notably Plato and Aristotle. Characterized in terms of "a general interpretative key against dogmatism and relativism" (p. 4), this approach relies on a key tenet: every aspect of reality is complex, and for that very reason it should be analyzed in many ways and from different perspectives. MIGLIORI goes on by proposing a threefold classification of what he defines "multifocality". According to this account, there is primarily (1) "a weak" multifocality when the same object is considered from two different points of view, as may be the case with a chair analyzed by a chemist and an interior designer. In a way, they both study the same chair, but are interested in different aspects. The second kind is (2) the "paradigmatic" multifocality, which implies that the object in question is analyzed by using different paradigms. In this context, the word "paradigm" should be intended in a Kuhnian way, as explicitly mentioned by MIGLIORI (p. 5). The third type of multifocality, (3) the "hermeneutic" one, is what MIGLIORI takes to be "the most radical" (p. 35), insofar as it modifies the object 
itself. This third account applies most straightforwardly to objects like texts, which are in fact influenced by the interpretation adopted to read them.

In what follows, I shall focus my attention only on some articles from each section rather than summarizing every article. The first part comprises contributions that deal with Heraclitus (Giacomo Teti), Plato (Lucia PalPacelli and Selene I. S. BrumanA), Proclus (Loredana CARdullo), Aristotle (Roberto MEdDA, Manuel BerRón and Arianna FERmANI), Isocrates (Maddalena VallozZA), and Nietzsche (Manuel KNOLL).

Giacomo TETI's article examines the notion of harmony in Heraclitus, by exploring one of the most famous Fragments concerning the theory of the unity of opposites (B 51). As is well known, in Fragment B 51 Heraclitus refers to the "reciprocal stretching harmony" of the bow and lyre, two opposite instruments that coexist in a harmonious unity in the god Apollo. Bow and lyre should not be disregarded as being simply opposites - this is only partially true - insofar as they can find a superior unity in the god Apollo. TETI emphasizes the opposition between the knowledge of the ordinary human being and the one reached by the truly wise person: while the former can only aim at a limited knowledge, the latter is able to collect every perspective in order to have a wider view on the world - "even the fragment is useful, if it is seen as a part of a whole and not as an isolated monad" (p. 41). According to the author, this also means that the fragmentary should not be disregarded as being false, but can turn to be useful and true on the basis of certain circumstances. Only the wise person, however, succeeds in moving from one system of thought to another, by embracing the intrinsic contrasts of the cósmos. This is, as I understand TETI's lines, the most significant contribution of Heraclitus to the debate on the multifocal approach.

Turn now to MEDDA's paper, which deals with Aristotle's multiple definitions of human being (ánthropos). The author aims to collect the definitions of human being in the Aristotelian corpus in order to show how they are connected and organized. MEDDA primarily focuses on the role of definitions in Aristotle. After taking up the lógos as the main characteristic of the human being, he argues that Aristotle's various definitions of human nature are to be understood in light of the assumption that human beings are rational animals. In doing so, MEDDA is interested in showing that these different formulations are examples of "the weak multifocality" that MIGLIORI outlines in his Introduction. This means that each definition accounts for a specific perspective and viewpoint on the same object, that is, the human being. For instance, MEDDA considers not only Aristotle's famous proposition that the human being is a "political animal" (zôon politikón), but also statements according to which the human being is described as "one who establishes a household" (zôon oikonomikón), "inclined to form a community" (koinonikón), "imitative" (mimetikón), and "two-footed terrestrial animal" (zôon pezón dípoun). Put together, these different descriptions take into consideration as many aspects as possible of the human life, from a formal and social level to a material one. Particularly interesting is also MEDDA's take on the human ability to laugh in Aristotle, as he shows that even this characteristic might stem from a high-order cognitive operation.

The second section of the issue treats the multifocal approach from a sociological and cultural standpoint. The breakdown of the articles is as follows. The first article (by Linda NAPOLITANO) deals with the relation between Socratic self-knowledge and the mediation process. The second (by Francesca EUSTACCHI) focuses on situational ethics, while the third (by 
Luca GRECCHI) offers a socio-historical contextualization of the multifocal approach. The fourth contribution (by Laura GHERARDI) explores the concept of social action from a sociological point of view. To conclude this section, there are two additional articles (by Roberto CRESTI and Lina CARACENI), which focus respectively on history of art and re-educational punishment.

The article that intrigued me the most is the one written by Francesca EUSTACCHI on situational ethics. Her argument is centered on a moderate version of situational ethics, which seems to be close to the multifocal approach and avoids both the absolutism and the relativism in the practical sphere. EUSTACCHI starts by briefly summarizing the thought of Ernst MICHEL, who proposed an ethical reflection that hinges on doing at the right moment what is requested by the situation (p. 131). After an initial overview, where EUSTACCHI interestingly gestures towards Gorgias's kairós, she turns to Edward SCHILLEBEECKX's version of situational ethics. From this account, EUSTACCHI defines the situation in terms of an "objective ethical norm" (p. 134). This means that, according to this version, situational ethics implies a strong normative element to be found in the situation itself rather than in theoretical principles that apply to every human being. With these ideas in mind, EUSTACCHI proposes an account of situational ethics that she defines multifocal, for it accounts for the complexity of moral life. This view mostly rests on three main assumptions. Firstly, it is necessary to identify some guiding principles that apply to everyone from a moral perspective. EUSTACCHI mentions as examples of guiding principles rationality, sense of responsibility, and tendency toward the common good. Secondly, these guiding principles serve as means of building moral maps and norms that take into account both the guiding principles and the situation in its concrete and material elements. Thirdly, there is the choice of the agent who acts in a certain situation to be considered. By connecting these three levels, EUSTACCHI argues for a multifocal situational ethics, which ranges from stable universal principles to variable and dynamic practical rules that consider the moral experience in its complexity.

The third and final section explores some examples of multifocal approach in the scientific and economic sphere. One of the contributions (by Roberto CICCOCIOPPO) focuses on mind and memory, while the remaining four contributions (by Giovanni LANZONE, Francesco RocCHETTI, Paola MAURI and Emanuele FRONTONI et al.) examine the economic side, and most notably, the sector of commercial enterprise.

I will delve here into Paola MAURI's paper in an effort to understand how the multifocal approach can be used in business analyses. MAURI focuses her attention on companies, which are defined as "complex and dynamic" structures (p. 201). On MAURI's view, there is more at stake for companies than just economical and financial values. The company's position in a territory, its reputation, connections and competencies are only some examples of other values to be accounted for. MAURI makes this case by arguing that the focus needs to be shifted from the shareholder to the stakeholder. She goes on by analyzing some kinds of stakeholders. For instance, with respect to the clients, MAURI notes that a company must handle their needs, which are various and changeable. A potential car buyer, say, is interested not only in the price of the car and in its comfort, but also in its environmental impact. "Companies' complexity can be described through the multifocality of the stakeholders" (p. 203), MAURI adds. She, finally, considers companies in light of the threefold classification that MIGLIORI proposes in the Introduction to the volume. Regarding weak multifocality, MAURI analyzes the different 
perspectives that one may adopt in considering a certain product (e.g., its quality, costeffectiveness, environmental impact and so on). This is mostly a descriptive approach. Paradigmatic multifocality involves a passage from the worker-entrepreneur relation to a more inclusive approach that hinges on such notions as "system," "context," and "stakeholders" (p. 208). When it comes to discussing hermeneutic multifocality, MAURI takes the case of the construction of a manufacturing plant. She argues that handling this stage "in a multifocal way" increases the productivity of the company itself (p. 209). What she means is that one should consider not only the fact that a manufacturing plant needs to be cost-effective and produces goods at competitive rates. What matters is also to ensure worker safety and a low environmental impact. MAURI concludes by arguing that companies must necessarily deals with this kind of multifocality in order to become competitive.

In summary, the volume succeeds in presenting the proposal of the so-called multifocal approach, by also providing a framework for further discussion about methodological issues and improvement of this paradigm. Any reader interested in these questions will benefit from this volume. 